\title{
Role of smectite-rich shales in frequent foundation failures in southeast Nigeria
}

\author{
Raphael Iweanya Maduka ${ }^{1, *}$, Nnadozie Onyekachi Ayogu ${ }^{1}$, \\ Chinero Nneka Ayogu ${ }^{2}$ and Gabriel Auodugu Gbakurun ${ }^{3}$ \\ ${ }^{1}$ Department of Geology, University of Nigeria, Nsukka, Nigeria. \\ ${ }^{2}$ Department of Geography, University of Nigeria, Nsukka, Nigeria. \\ ${ }^{3}$ Department of Geology, University of Jos, Jos, Nigeria. \\ *Corresponding author.e-mail: mycommunity@yahoo.com
}

This paper investigated the geotechnical properties of smectite-rich shale, and its implications as foundation material. Ten expansive shale samples were collected from foundation materials at Akpugo in Nkanu West L.G.A. of Enugu State, southeast Nigeria. Samples were subjected to grading, Atterberg limitscum-compaction tests, slake durability, specific gravity, permeability, undrained triaxial tests and x-ray diffraction scan. Fines and sand contents of the soil samples range from $51-97 \%$ and $3-49 \%$ respectively. Liquid limit, plastic limit and plasticity index have average values of 60.7, 19.1 and $43.3 \%$ respectively. Linear shrinkage and free swell showed average of $16.3 \%$ and $76 \%$. These results are indicative of predominant clay soil with high plasticity, compressibility and water holding capacity. XRD scan established presence of smectite and illite clay minerals, confirming soil high plasticity, capable of causing instability in foundation soil. The shale achieved maximum dry density range between 1.79 and $1.94 \mathrm{~kg} / \mathrm{m}^{3}$ at optimum moisture content range of $6.9-12.8 \%$, indicating poor to fair foundation materials. The shale cohesion ranges from 15 to $30 \mathrm{kPa}$ while the angle of friction ranges between $10^{\circ}$ and $18^{\circ}$, signifying an average strength soil material. Samples slake durability index and specific gravity fall within $24-55 \%$ and 2.50-2.58 respectively, suggesting non-durable and weak soil. Permeability of the samples ranges between $7.36 \times 10^{-6}$ and $4.77 \times 10^{-8} \mathrm{~cm} / \mathrm{s}$ which suggested low drainage capable of causing water-log at sites. Therefore, the shale could be generally classified as poor to fair foundation material, which on moisture influx experience reduction in strength due to deterioration of its constituent minerals, especially clay and cement materials during the lifespan of engineering structures. Authors therefore recommend modification of foundation soil, appropriate foundation design and good drainage control as ways of improving stability of engineering structures underlain by expansive shale.

\section{Introduction}

Clay soil is difficult to manage during construction (Adesunloye 1987; Agbede and Smart 2007). However, it is one of the most predominant sedimentary rocks, covering a vast area of the earth surface. Frequently, it is encountered while laying foundations and at other sites where economic and environmental considerations have necessitated its use (Le et al. 2012; Sarkar et al. 2012; Vishal et al. 2015a, b). Pivotal in foundation and highway failures are clay soils which have formed the link of most researches. Aghamelu et al. (2011a), Pradhan et al. (2014) and Vishal et al. (2015a, b) decried such palpable geotechnical behaviour exhibited by clay and posited that it has a concern

Keywords. Expansive shale; foundation failure; weathering; moisture; smectites; clay minerals. 
for environmental and geotechnical issues. On a large scale, construction problems associated with shale is underscored by mineralogy, orchestrating from the predominant clay mineral type(s) - montmorillonite and illite (Obiora and Umeji 2004).

Focal in previous studies are other factors that influence shale activity in foundation failures. They include climate and physiography, soil particles arrangement, confining pressure, type and degree of weathering as related to the initial water content and water chemistry of the area under consideration (Nelson and Miller 1992; Mitchell 1993; Ezeribe 1994; Johnson and Snethen 1978) while findings from Sharma et al. (2007), Singh et al. (2006), Singh and Verma (2005) and Gupte et al. (2013) orient towards the inherent low shear strength, low durability, high plasticity and high compressibility inherent in clay.

Foundation failure is a challenge to many settlements in our study area and has bedeviled numerous engineering structures underlain by Awgu Shale which composes several foundation beds in villages and towns, viz., Agwu, Nara, Agbani, Amagunze, Owo, Obugu and Akpugo (figure 1). The present study was carried out at Obinagu Uwani community in Akpugo, a town in Nkanu West Local Government Area of Enugu State, southeast Nigeria. The community had shown more devastation of foundations and highways than any other locality within the area. Regrettably, most engineering structures built on shallow foundations on the clay have shown critical wall damages in the form of longitudinal cracks that could open to about $1.0 \mathrm{~cm}$ in diameter (figure 2a). The parts of the structure mostly affected are the foundations, walls, floors and slabs. Oftentimes, the cracks develop even at the end of the first wet season after their construction (Lew 2010) as shown in figure 2(b). This has contributed to collapse in any developmental project undertaken despite the architectural design, meticulous, painstaking attention and accuracy in measurement displayed by the builders. To this end, construction failures traceable to clay soil should not be left in a state of obscurity or be allowed to remain marginal.

Cracks on building floors and walls are linked to the cracks on the foundation soils which precedes it. Soils in the area crack during the dry season when moisture is reduced as a result of the release of water from the clay sheets through gravitational forces or evaporation, thereby, causing the overall volume of the soil to decrease or shrink. However, during the rainy season, clay adsorbs water through osmosis or hydration in the form of adsorbed water on the clay minerals which makes the cracks disappear due to the clay expansion. Shrinking predisposes soil to the development of gross feature - void or desiccation crack. These shrinkage cracks are visible on the surface of bare soils, and sometimes penetrate deep into the ground with the maximum width usually limited to $20 \mathrm{~mm}$ (Arora 2008), as presented in figure 2(c). Nevertheless, the desiccation cracks disappear when the soil expands during the rainy season, as soil water content is increased, providing an important indication of expansive soil activity. This shrink-swell behaviour of the soil could be a result of mineralogy, and clay minerals are mostly responsible for such a characteristic (Sowers and Sower 1970).

Reinforcing this observation on failure of engineering structures and expansive soil behaviour ascribed to clay units are structural failures in the Imo Shale underlying some parts of Awka (Aghamelu et al. 2011a) and road failures in the potholes in Abakiliki metropolis, within the Asu-River Shale (Aghamelu et al. 2011b). The predominant soil type underlying the problematic engineering structures in the present study area is clay belonging to the Awgu Shale group in the Anambra Basin. Among all tested expansive clay units (Asu-River, Imo, Enugu and Nkporo formations) underlying the Anambra Basin, Awgu Shale exhibited the highest expansive nature and consequently, lower strength characteristics (Adesina et al. 2012; Ekeocha 2014). Aghamelu et al. (2011a) suggested that the conversion of high expansive clay into less expansive types could be the reason for lower plasticity index of the Imo Shale. Given the above scenario, it is unarguable that the highest level of priority should be the conversion of high expansive clay minerals into less expansive types as a way of cushioning the high plasticity index of the shale unit.

The critical expansiveness of Awgu Shale necessitated the present study, and the novelty of this study is the consideration of its slaking durability index in order to ascertain the weatherability of this clay formation. We now make a submission that unless preventive or safety measures are adopted, this soil cannot support foundation of engineering structures. As a sequel, the mineralogical compositions of the Awgu Shale and their influence on its swelling potential and geotechnical behaviour, will not occupy a subaltern position in this paper. Thus, we will offer clarifications on the general causes of extensive manifestation of foundation failures on expansive clays and make suggestions on design and maintenance methods of such engineering structures.

\subsection{Location and accessibility of the study area}

The study site is located at Akpugo, a town in Nkanu West Local Government Area of Enugu State, southeast Nigeria. Akpugo is bounded within 


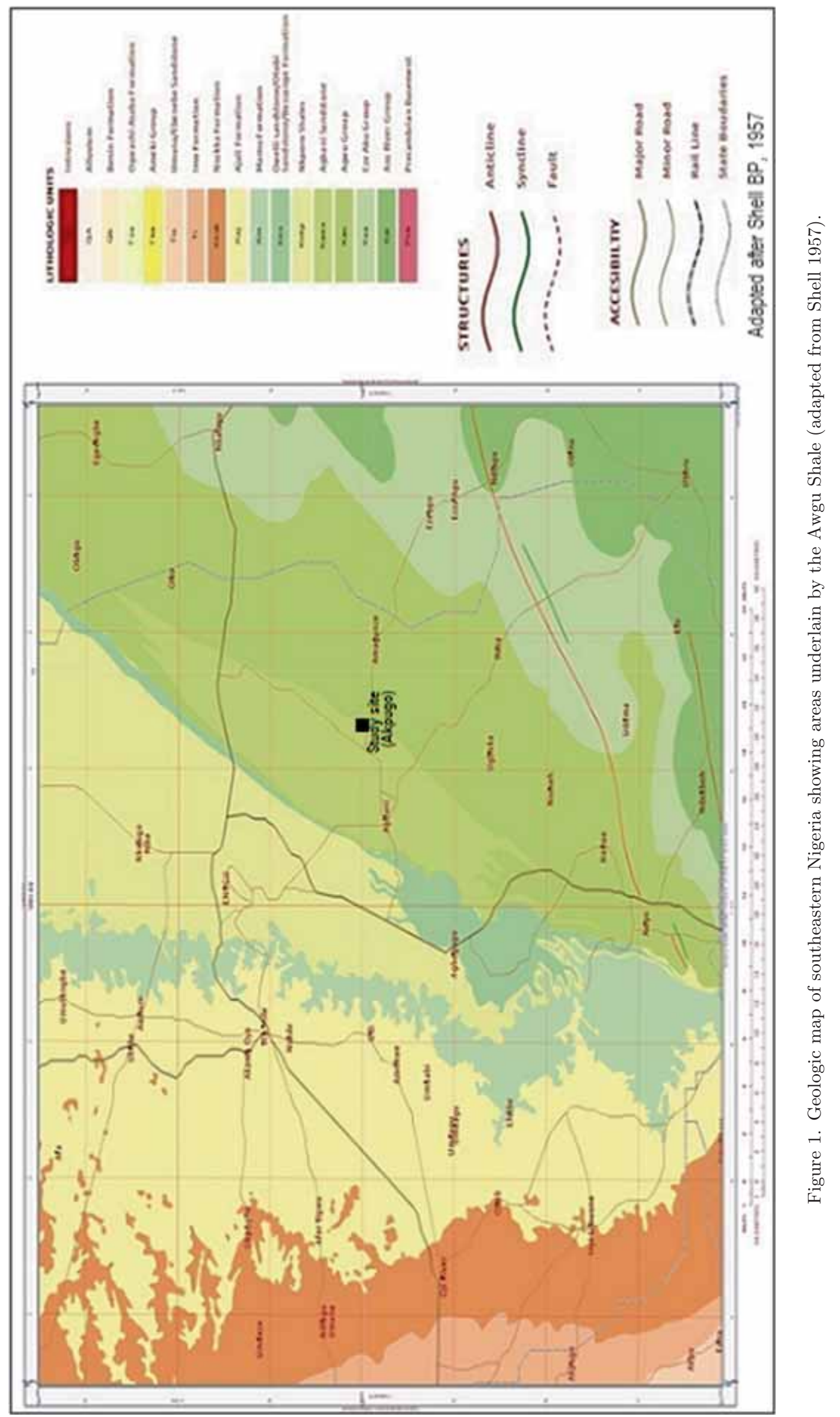




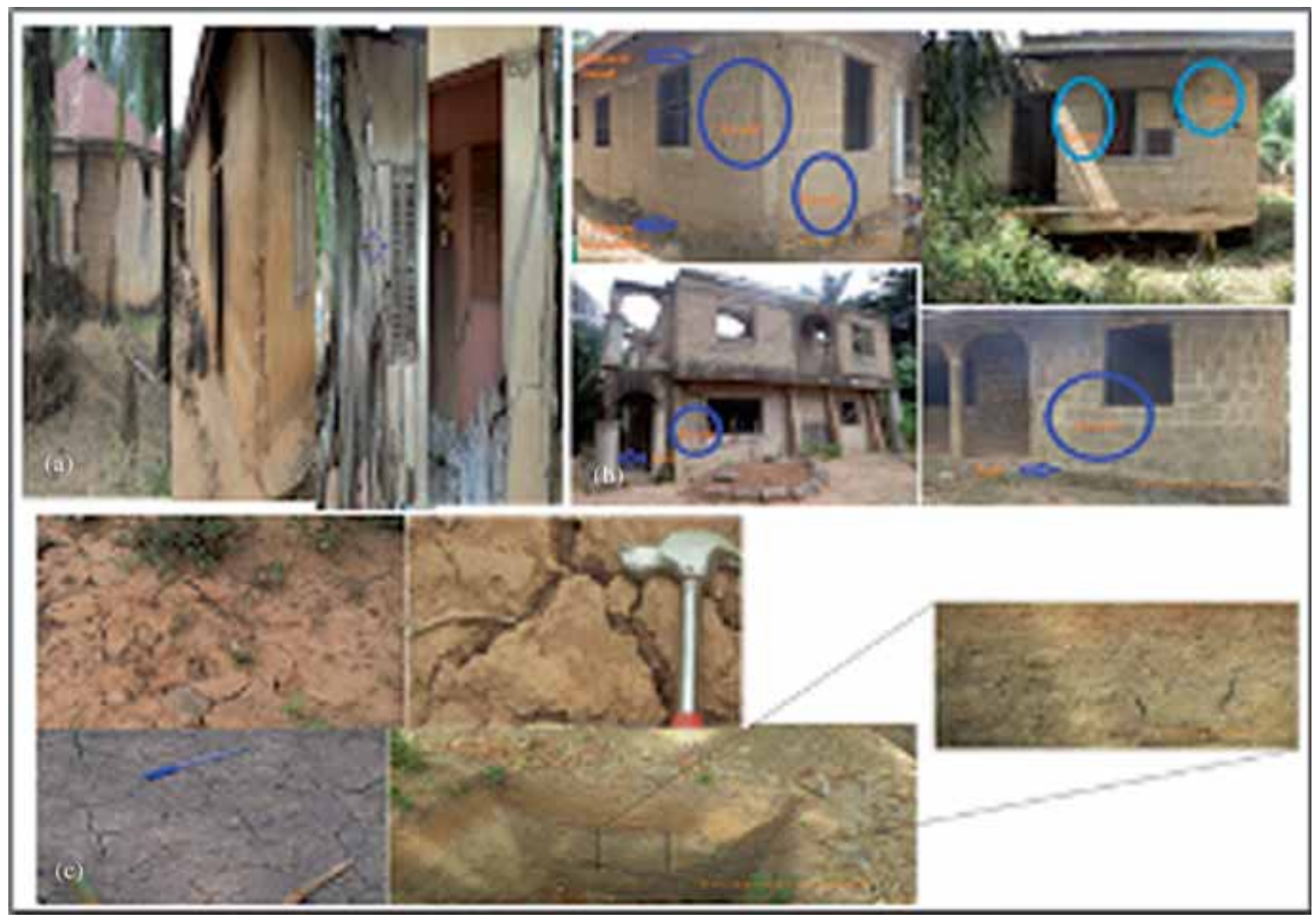

Figure 2. Evidences of expansive soils.

latitudes $6^{\circ} 17^{\prime}-6^{\circ} 20^{\prime} \mathrm{N}$ and longitudes $7^{\circ} 35^{\prime}-7^{\circ} 38^{\prime} \mathrm{E}$. The area spans approximately $25 \mathrm{~km}^{2}$ (figure 3 ). It lies about $15 \mathrm{~km}$ southeast of Enugu - the state capital and about $4 \mathrm{~km}$ northeast of Agbani. The main access route is the tarred Agbani-AkpugoAmagunze road (figures 1 and $3 \mathrm{~b}$ ). The network of untarred roads and track routes transecting the mapped area was beneficial in the course of study because it en-route other villages.

\subsection{Climate}

Prevailing in the area is heavy rainfall typical of the rainforest region of the tropics (Aw) climate of the Koppen classification. Annual rainfall ranges from 1850 to $2500 \mathrm{~mm}$, usually accompanied by violent storms of high intensity. The area experiences two distinct seasons - the rain and dry seasons with seven months of effective rainfall, starting from April to October because of the southwest Trade wind and five months of dry season (NovemberMarch). The highest amount of rains are recorded within the months of May and July, just before the August break, identified as the 'little dry season' during which the rainfall ceases, before resuming in late August to October. The dry season has a characteristic dry wind emanating from the northeast Trade wind locally known as 'harmattan'. It dominates most of November to March. During the dry season, average monthly maximum temperatures of up to $34^{\circ} \mathrm{C}$ are recorded, whereas the lowest average monthly minimum temperature that could be logged is $20^{\circ} \mathrm{C}$ especially during the peak of the rainy season. Pressure ranges from 1010 to 1012.9 mbar (Monanu and Inyang 1975).

\subsection{Geology of the area}

The formation of the southern Nigeria sedimentary basin followed the break-up of the South American and African continents in the Early Cretaceous (Murat 1972). Several authors have used structural, stratigraphic, geomorphologic and palaeonotologic evidence to support a rift model of the basin (Reyment 1969; Petters 1978; Benkhlil 1989; Oyedim et al. 2009; Igwesi and Umego 2013; Okiwelu et al. 2015). The development of the Benue Trough provided the main structural control and framework for the subsequent geologic evolution of the region. The stratigraphic history of the region is characterized by three sedimentary phases (Murat 1972; Obi et al. 2001). 

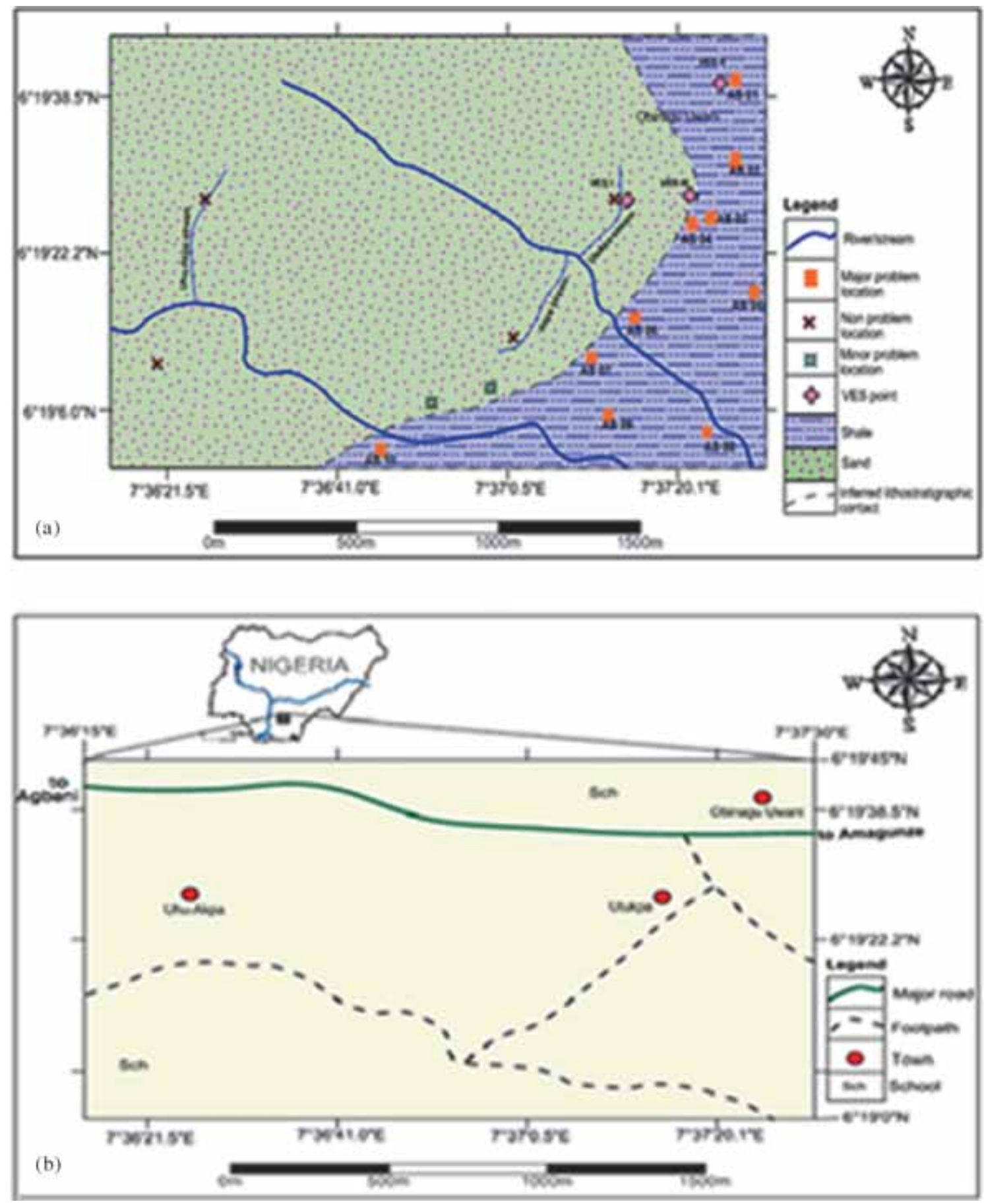

Figure 3. Lithologic map of the study area showing sample collection points.

The study area belongs to the first marine sedimentary phase which was the deposition of about $3000 \mathrm{~m}$ of rocks comprising of the Asu-River Group, Eze-Aku and Agwu Group Formations in the Anambra-Benue Basin during the Albian, Turonian and Coniacian ages, respectively (figure 4). The Asu River Group is the earliest recorded marine sediments consisting of bluish grey to brown shale, sandy shale, fine-grained micaceous sandstones, and dense blue limestone (De-Swardt and Casey 1963; Reyment 1965). The sediments of the
Eze-Aku Formation consist of hard grey to black shales and siltstones with frequent facies alternation of sandstone or sandy shale (Reyment 1965).

The Agwu Group, which is the main geologic formation that outcropped in the study area, consists of the Agwu-Ndeaboh Shale and Agbani Sandstone (Reyment 1965). The Awgu Formation is characterized by bluish grey, well-bedded shales with intercalations of fine-grained sandstones and often thin marshy and shelly limestone, while the Agbani Sandstone consists of medium-coarse grained 


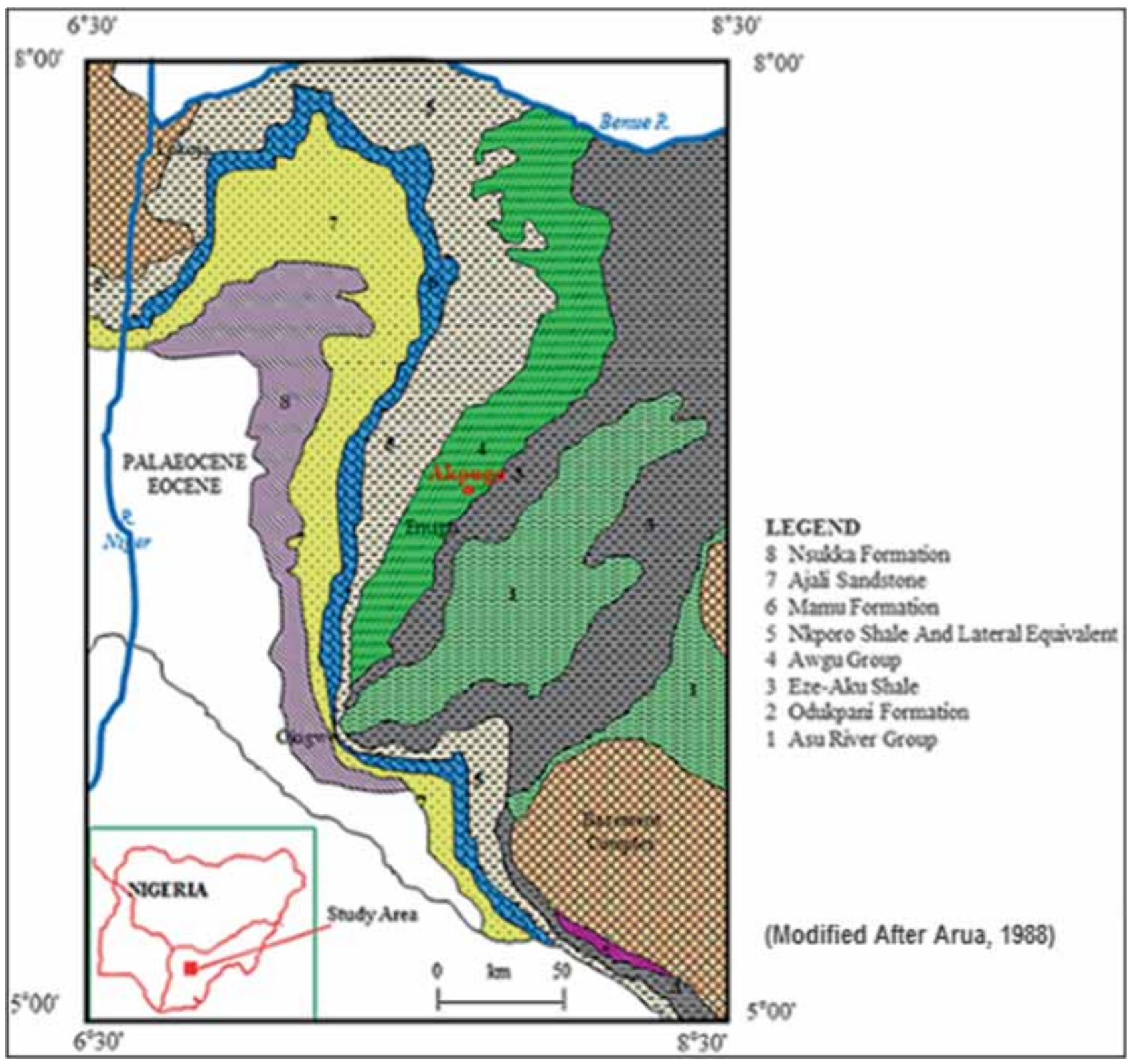

Figure 4. Regional sedimentary history of the southern Benue Trough (modified after Arua 1988).

bioturbated sandstone which is often pebbly with laminated brownish clays and pyritic carbonaceous shale.

Reyment (1965) thought both formations to be equivalent in age, deposited during the Turonian, and thus intercalated. Conversely, Cratchley and Jones (1965) believed that the Agbani Sandstone was a later deposit which accompanied the regression 'shallowness' of the Coniacian Sea. However, Benkhelil (1986) noted that the Agwu Shale estimated to be $900 \mathrm{~m}$ thick is marked by a fossiliferous horizon containing Turonian fossils at the base and another horizon at the top which is Coniacian. Kogbe (1989) found the Awgu Shale to be rich in ammonite and other mollusks, which is an indication of a marshy, deltaic and shallow marine deposit (Obaje 1994).

\section{Materials and methods}

\subsection{Detailed field work and sample collection}

The study of the shale was carried out systematically in two phases, which included field work and laboratory studies. The field work involved preliminary studies, reconnaissance and detailed mapping along with a consultation of previous works carried out on the study area both on a regional and local scale. Oyedim et al. (2009), Igwesi and Umego (2013) and Okiwelu et al. (2015) were studied to acquaint ourselves with vital information on the regional geologic, stratigraphic and tectonic settings of the area.

In the course of the field work, 10 samples labeled AS 01-10 were collected from the shallow 
Table 1. Physical properties and mineral compositions of the studied samples.

\begin{tabular}{|c|c|c|c|c|c|}
\hline $\begin{array}{l}\text { Sample } \\
\text { no. }\end{array}$ & $\begin{array}{l}\text { Sampling } \\
\text { depth }(\mathrm{m})\end{array}$ & Sample type & Physical properties & Clay minerals & Non-clay minerals \\
\hline AS 01 & 1.3 & Weathered & $\begin{array}{l}\text { Light brown with yellowish } \\
\text { mottles, massive, smooth } \\
\text { feel with fine sand }\end{array}$ & $\begin{array}{l}\text { Illite, Smectite, } \\
\text { Kaolinite }\end{array}$ & $\begin{array}{l}\text { Calcite, Hematite, } \\
\text { Quartz, Osumilite }\end{array}$ \\
\hline AS 02 & 1.0 & Weathered & $\begin{array}{l}\text { Whitish grey, fissile, very fine } \\
\text { smooth feel }\end{array}$ & $\begin{array}{l}\text { Smectite, Illite, } \\
\text { Kaolinite }\end{array}$ & $\begin{array}{l}\text { Hematite, Albite, } \\
\text { Quartz, Calcite }\end{array}$ \\
\hline AS 03 & 1.1 & Fresh & $\begin{array}{l}\text { Brownish grey with yellow } \\
\text { mottles, massive, slightly gritty }\end{array}$ & $\begin{array}{l}\text { Kaolinite } \\
\text { Sapiolite }\end{array}$ & $\begin{array}{l}\text { Hematite, Quartz, } \\
\text { Calcite }\end{array}$ \\
\hline AS 04 & 1.5 & $\begin{array}{l}\text { Slightly } \\
\text { weathered }\end{array}$ & $\begin{array}{l}\text { Light brown, massive, fine } \\
\text { smooth feel }\end{array}$ & $\begin{array}{l}\text { Kaolinite, Illite } \\
\text { Smectite }\end{array}$ & $\begin{array}{l}\text { Feldspar, Albite, } \\
\text { Muscovite, Quartz, }\end{array}$ \\
\hline AS 05 & 1.3 & Weathered & $\begin{array}{l}\text { Yellowish brown with orange } \\
\text { stains, massive slightly gritty }\end{array}$ & $\begin{array}{l}\text { Kaolinite, Chlorite, } \\
\text { Sapiolite }\end{array}$ & $\begin{array}{l}\text { Quartz, Mica, Quartz, } \\
\text { Anthrophylite }\end{array}$ \\
\hline AS 06 & 1.5 & Weathered & $\begin{array}{l}\text { Light brown, massive, fine } \\
\text { smooth feel }\end{array}$ & $\begin{array}{l}\text { Smectite, Illite, } \\
\text { Kaolinite }\end{array}$ & $\begin{array}{l}\text { Quartz, Muscovite, } \\
\text { Albite, Anthrophylite }\end{array}$ \\
\hline AS 07 & 1.4 & $\begin{array}{l}\text { Slightly } \\
\text { weathered }\end{array}$ & $\begin{array}{l}\text { Brownish grey with yellow } \\
\text { mottles, massive, smooth } \\
\text { feel with fine sand }\end{array}$ & $\begin{array}{l}\text { Smectite, Illite, } \\
\text { Kaolinite }\end{array}$ & $\begin{array}{l}\text { Hematite, Muscovite, } \\
\text { Calcite, Quartz }\end{array}$ \\
\hline AS 08 & 1.2 & Weathered & $\begin{array}{l}\text { Yellowish brown with orange } \\
\text { stains, massive smooth feel } \\
\text { with fine sand }\end{array}$ & $\begin{array}{l}\text { Smectite, Illite, } \\
\text { Chlorite }\end{array}$ & $\begin{array}{l}\text { Anthrophylite, Quartz, } \\
\text { Feldspar, Calcite, } \\
\text { Osumilite }\end{array}$ \\
\hline AS 09 & 1.3 & Fresh & $\begin{array}{l}\text { Light brown with yellowish } \\
\text { mottles, massive, gritty feel }\end{array}$ & $\begin{array}{l}\text { Illite, Chlorite, } \\
\text { Kaolinite, Sapiolite }\end{array}$ & $\begin{array}{l}\text { Albite, Muscovite, } \\
\text { Quartz, Mica, Calcite }\end{array}$ \\
\hline AS 10 & 1.0 & $\begin{array}{l}\text { Slightly } \\
\text { weathered }\end{array}$ & $\begin{array}{l}\text { Light brown with yellowish } \\
\text { mottles, massive, slightly } \\
\text { gritty feel }\end{array}$ & Chlorite, Illite & $\begin{array}{l}\text { Quartz, Calcite, Mica, } \\
\text { Hopeite, Feldspar }\end{array}$ \\
\hline
\end{tabular}

foundations of devastated buildings, as shown in figure 3(a). At each station, longitude and latitude values and detailed description of outcrops based on lithology, texture, structure and colour were all taken into cognizance (table 1). The weathered samples, typical of A and B soil horizon in southeastern Nigeria were collected between 1 and $1.5 \mathrm{~m}$ depth, and were placed in black sample bags and transported to the laboratory for analysis within $48 \mathrm{hrs}$ after collection.

\subsection{Laboratory testing}

Sample preparation and laboratory testing to define the geotechnical and mineralogical properties of Awgu Shale were performed in accordance with the specifications of ASTM (American Society for Testing and Materials) and BSI (British Standard Institution). Parameters investigated in the laboratory include particle size distribution, specific gravity, compaction analysis for maximum dry density and optimum moisture content, undrained triaxial compression for the shear strength parameters and Atterberg limit tests.

Particle size distribution (PSD) were performed in accordance with ASTM D421 (1994) standard test method for particle size distribution (gradation) of soils using sieve analysis (for the fraction passing 2, 0.425 and $0.075 \mathrm{~mm}$ ASTM sieve opening). Particles (silt+clay) passing the sieve were collected and passed through sedimentation analysis as outlined by Kettler et al. (2001) and ASTM D422 (2007) standard test method for particle size analysis of soils (hydrometer analysis of percent passing $2 \mu \mathrm{m}$ ASTM sieve opening which is predominantly clay fraction) to determine the clay percentage in samples. Clay compaction was measured in accordance with ASTM 689 standard test method for laboratory compaction characteristics of soil using standard efforts $\left(600 \mathrm{kN}-\mathrm{m} / \mathrm{m}^{3}\right)$. Consistency limits were determined in accordance with ASTM D4318-05 standard test method for liquid limit, plastic limit and plasticity index of soils. The samples shear strength was tested by consolidated undrained compression test following the BSI 1377 (1990) standard. Weatherability of the samples was evaluated using ASTM D4644-90 standard test method for durability of shale and similar weak rocks.

Crushed shale samples that were oven-dried at $105^{\circ} \mathrm{C}$ for 24 hours to exclude air and water were utilized in the determination of the specific gravity. The test was carried out with the aid of a $100.15 \mathrm{ml}$ pycnometer bottle and water (distilled water) distilled at $27^{\circ} \mathrm{C}$ with specific gravity of 0.9965 . The laboratory procedure follows the testing method 
outlined by Lambe (1951). Mineral compositions of the samples were examined using X-Ray Diffraction (XRD), available at the National Steel Raw Materials Exploration Agency, Kaduna, Nigeria.

\section{Results and discussions}

\subsection{Result}

The samples exhibited a wide range of variability in their geotechnical characteristics, as shown in table 2. The PSD result revealed that the content of sand, silt and clay in the Agwu Shale unit are $3-49 \%$ (4.76-0.074 mm grain size), $1.3-3.7 \%$ and $48.7-95.2 \%$, respectively. The Atterberg limits indicated that liquid limit (LL) ranges from 44.5 to $78.0 \%$, Plastic limit (PL) ranges between 16.5 and $21.9 \%$ and plasticity index (PI) ranges from 23.1 to $56.1 \%$ (table 2). The Free Swell (FS) of the tested samples range between 30 and $145 \%$ while natural moisture content (NMC) measured was observed to be between 7.2 and $14.6 \%$. The samples have bulk density (BD) ranging from 1.5 to $2.2 \mathrm{Mg} / \mathrm{m}^{3}$. Compaction result showed maximum dry density (MDD) ranges between 1.79 and $1.94 \mathrm{~kg} / \mathrm{m}^{3}$ while optimum moisture content (OMC) ranges from 6.9-12.8\%. Cohesion and friction angle of the shale ranges from 15 to $30 \mathrm{kPa}$ and $10-18^{\circ}$ respectively. Samples specific gravity (Gs) falls within 2.50 and 2.58. Permeability $(\mathrm{k})$ of the samples ranges between $7.36 \times 10^{-6}$ and $4.77 \times 10^{-8}$ $\mathrm{cm} / \mathrm{s}$. The clay minerals recorded by XRD scan were smectite, illite, kaolinite and chlorite, while the non-clay minerals were quartz, hematite, calcite and feldspar (table 1).

\subsection{Particle size analysis and permeability}

The summary of the laboratory test results is presented in table 2. Samples AS 01-10 have the following range of size distribution: fines, fine sand, and medium sand and coarse sand. Coarse sand in samples ranges from 1.0 to $3.0 \%$ while medium and fine sands range between $1.0-9.0 \%$ and $1.0-37.0 \%$, respectively. The fines content ranges between 51.0 and $97.0 \%$ within the samples; silt size content ranges from 1.3 to $3.7 \%$ while clay particles range between 48.7 and $95.2 \%$. The grain size distribution curves are shown in figure 5 . According to Arora (2008), a curve situated higher up and to the left indicated, in general, a relative fine-grained soil which has its own peculiar engineering properties and behaviour during earthworks.

The PSD was confirmed by the result of the constant separation traversing (CST) done within the shale in-situ (figure 6a). Using the qualitative engineering competence of soils as shown in table 3 , the soil can be evaluated from layer resistivity. A large percentage of the shale, about $83 \%$ is incompetent soil for engineering projects, which is mostly clay with resistivity of less than $100 \Omega \mathrm{m}$ as shown in figure 6(b) (Sheriff 1991). The competent soil mostly known to be sand with resistivity of greater than $100 \Omega \mathrm{m}$ was $17 \%$ of the soil.

The clay samples have permeability values ranging from $4.77 \times 10^{-8}$ to $7.36 \times 10^{-6} \mathrm{~cm} / \mathrm{s}$. This implies that the shale is liable to water-log during rainy seasons due to low drainage, especially with increasing rainfall in recent times (figure 7). The high water content could initiate weathering and clay activity within the soil. Result of the clay slake durability test attests to the weatherability of the clay samples. The slake durability index $\left(\mathrm{I}_{\mathrm{d}}\right)$ of the tested clay ranges between 24 and $57 \%$, indicating a very low to medium durability according to Bell (2007) grading shown in table 4 . Thus, the clay is liable to gross weathering.

\subsection{Mineral composition and specific gravity}

Asere et al. (2002) and Adeyemi (2002) emphasized the influence of amount and type of clay minerals on the geotechnical properties of construction materials. The affinity which a soil has for water depends on the predominant clay minerals, and thus impact on the stability of earthworks.

The XRD scan results revealed that shale contains clay minerals such as smectite (montmorillonite), illite, kaolinite (kaolinite-serpentine group such as lizardite and chrysotile), chlorite (clinochlore) and sepiolite (figure 8 and table 1 ). These clay minerals significantly influence engineering behaviour of shale due to their high activity. Other minerals present in samples are phlagopite, osumilite, hopeite and anthophyllite, which can also undergo weathering to produce other swelling clay minerals such as beidellite and vermiculite (USGS 2001). Silicate minerals detected (figure 8) such as feldspars (sanidine), mica (muscovite) and amphibole (anthrophyllite) are common constituents of expansive shale but do not contribute to the expansiveness of the soil due to their low activity. However, these minerals could weather as revealed by the low slake durability index of the clay (table 2) to form expansive clay mineral. Clay minerals could be the main factor influencing the slake durability of rocks (Liu and Lu 2000).

Specific gravity $\left(\mathrm{G}_{\mathrm{s}}\right)$ is a reflection of densities of the materials in each sample exclusive of the permeable void they contain (Arora 2008; Garg 2011). The samples have specific gravity range between 2.50 and 2.58 (table 2). These $\mathrm{G}_{\mathrm{s}}$ fall within the specific gravity of clay minerals, which ranges from 


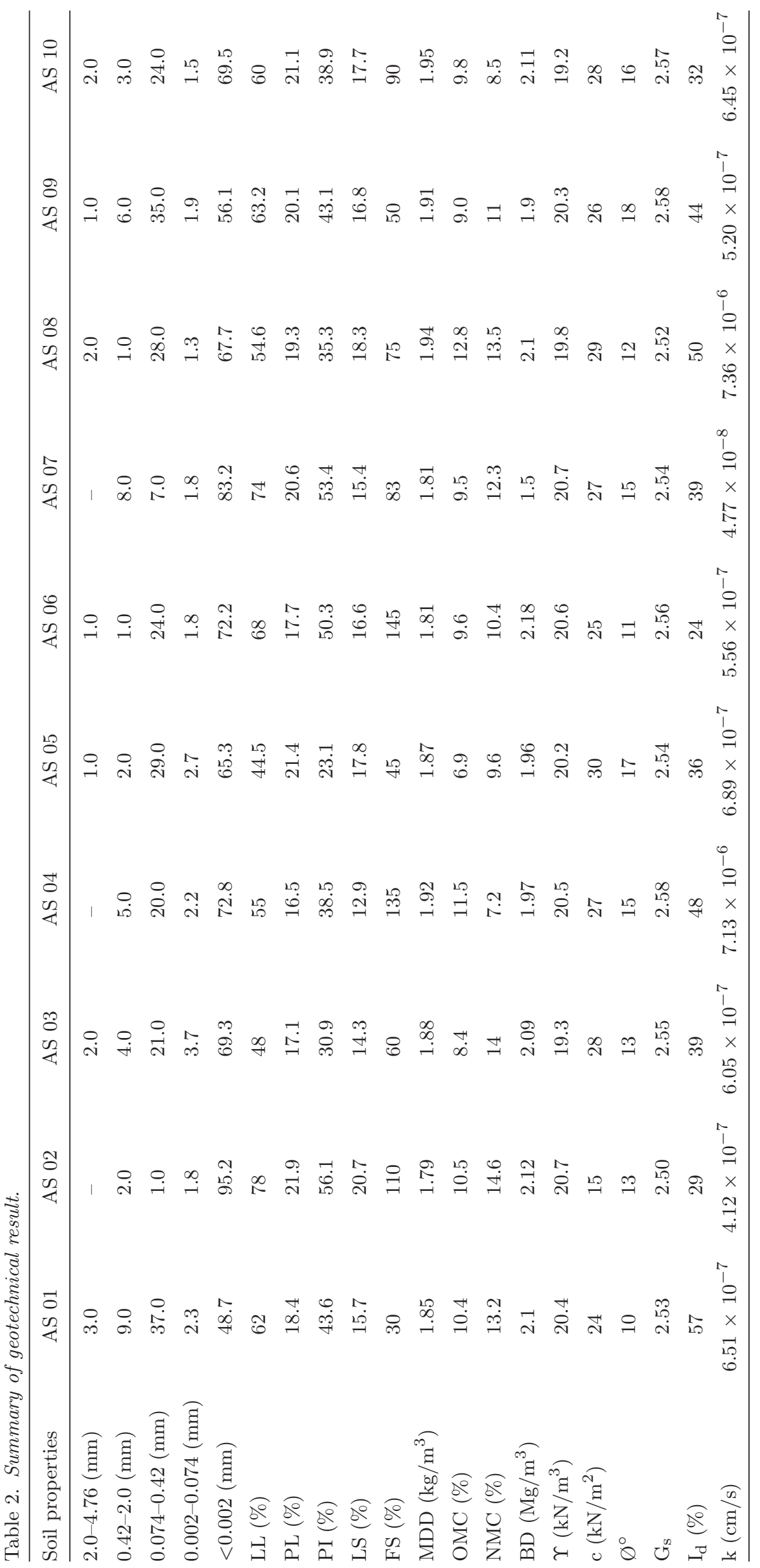




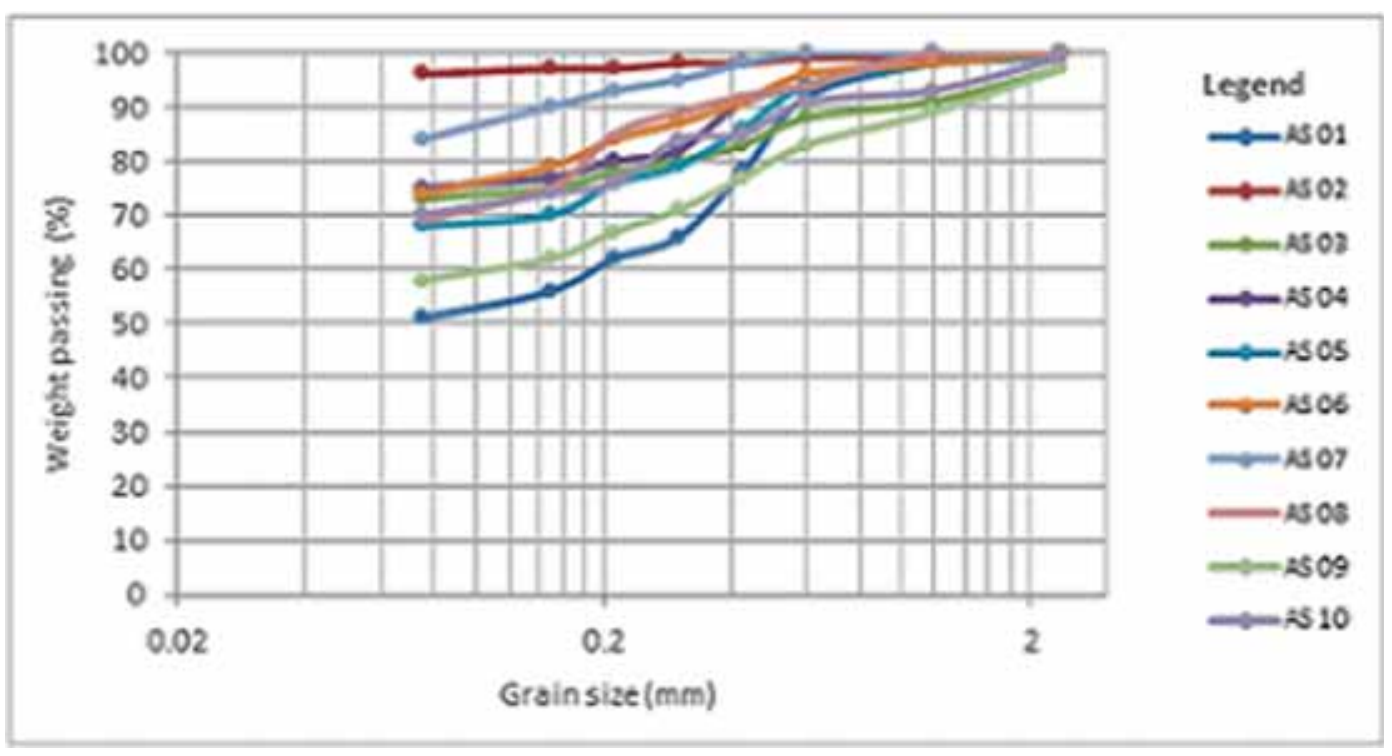

Figure 5. Samples particle size distribution curves.

2.44 to 2.92 (Emesiobi 2000). Thus, low values of $\mathrm{G}_{\mathrm{s}}$ of the tested samples could be attributed to the presence of clay minerals.

Specific gravity could be used as a quick identifier of poor aggregates (Krynine and Judd 1957). Reidenouer (1970) stated that rocks of specific gravity as low as 2.65 are usually weak and non-durable. Therefore, low specific gravity could impact on maximum dry density and shear strength of shale.

\subsection{Consistency limits}

The most important characteristic of a clay soil is its plasticity (Berry and Reid 1987). The consistencies of natural clay vary significantly with increase in water content. The result of the Atterberg limit tests is presented in table 2. The LL for the samples ranges between $44.5 \%$ and $78 \%$, while the PI varies from $23.1 \%$ to $56.1 \%$. The samples are classified as medium to very high plastic clayey soils (table 5 ). However, sample AS 05, as seen in table 2, could be classified as low plasticity (Tadanier and Nguyen 1984). Samples AS 02 and 07 had the highest clay content (95.2\% and $83.2 \%$ ) and thus showed higher plasticity with LL and PI of 78 and $56.1 \%$ and 74 and $53.4 \%$, respectively (table 2 ). This shows that within similar clay mineralogy, amount of clay fraction seems to govern the magnitude of the swelling potential.

The plasticity chart classification of the samples is displayed in figure 9. All the samples plotted above the A-line, an indication of expansive soils (Van der Merwe 1964). All samples except AS 03 and 05 plotted on the right of the vertical line crossing LL equal to $50 \%$, indicating high compressibility as shown in table 6 (Bell 2007; Lew 2010). The shale also showed high activity (figure $9 \mathrm{~b}$ ), which is as a result of influence of dominant minerals within the clay.

According to the Unified Soil Classification System (USCS), using soil plasticity chart, the shales are classified either as inorganic fat clay of high plasticity $(\mathrm{CH})$ and/or inorganic clay of medium to high plasticity (ML) (Garg 2011). However, shale can also be classified as A-7-6 using particle size distribution and plasticity chart (AASHTO classification system). It has been noted that $\mathrm{CH}$ soils are associated with poor-fair compaction, high compressibility, high expansive characteristics, low drainage and poor-fair stability as fill material and aggregate when exposed to moisture (Sowers and Sower 1970; Aghamelu et al. 2011a).

The PI values of the samples are greater than the upper limit of $25 \%$ recommended for sub-base and sub-grade materials in tropical Africa by the French (Adeyemi 2002; Olayanju 2011). The high plasticity could be attributed to the presence of montmorillonite and other swelling clay minerals. Thus, samples are found to be unsuitable for sub-base and sub-grade foundation materials as seen in figure 2 .

The shale exhibited moderately high linear shrinkage (SL). Sample AS 01-10 have average linear shrinkage of $16.3 \%$ (table 2). This result of SL of the shale agrees with the PI values. The SL values indicated that the shale is likely to pose significant field compaction problems (Olayanju 2011; Adeyemi 2002). The SL values are higher than the maximum value of $8 \%$ recommended for sub-base materials (Madedor 1983; Olayanju 2011). However, high SL indicated that erosion may not pose a problem in the area due to the cohesion of plastic clays (Olayanju 2011). 


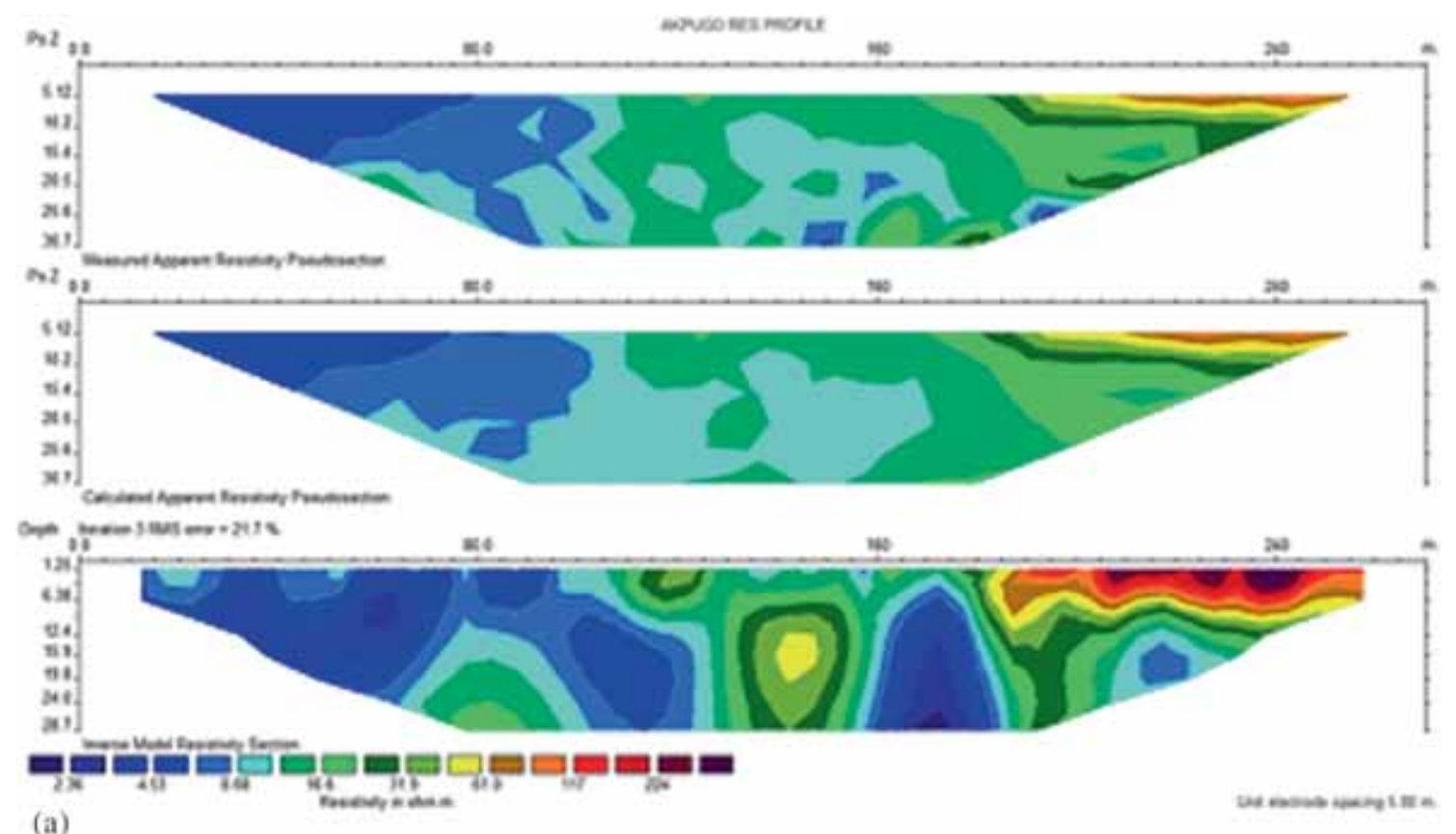

(a)

\section{Study area foundation soil rating}

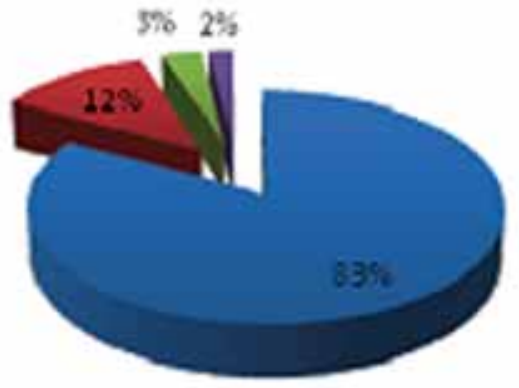

Incompetent

a Moderately competent

a Competent

a Highly coespetent

(b)

Figure 6. Resistivity profile model and particle size percentage of the study area.

Table 3. Lithologic competence rating in terms of apparent resistivity values (Sheriff 1991).

\begin{tabular}{|c|c|c|}
\hline $\begin{array}{l}\text { Apparent } \\
\text { resistivity } \\
\text { range }(\Omega \mathrm{m})\end{array}$ & Lithology & $\begin{array}{l}\text { Competence } \\
\text { rating }\end{array}$ \\
\hline$<100$ & Clay & Incompetent \\
\hline $100-350$ & Sandy clay & Moderately competent \\
\hline $350-750$ & Clayey sand & Competent \\
\hline$>750$ & Sand/laterite/bedrock & Highly competent \\
\hline
\end{tabular}

Table 2 shows that samples AS $01-10$ have FS range of 45-145\%. Holtz and Kovacs (1981) and Garg (2011) have reported that soils having free swell values as low as $100 \%$ may show considerable volume change under light loads when wetted, and

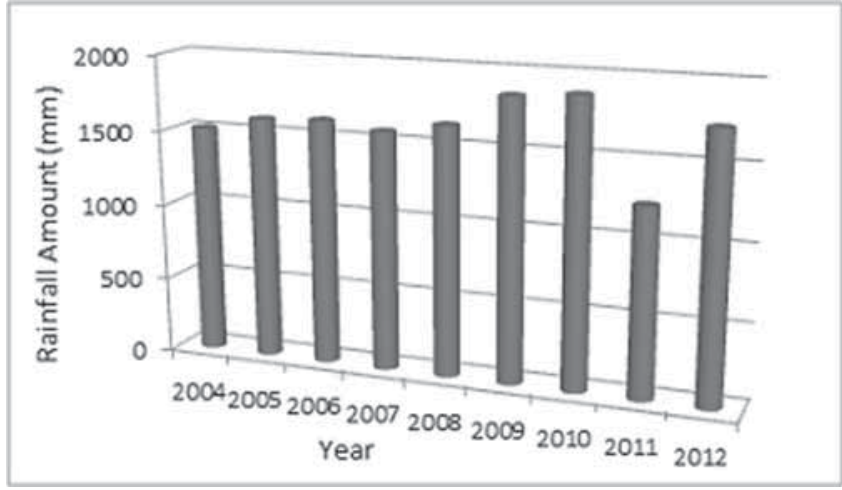

Figure 7. Rainfall trend of Enugu State, southeast Nigeria. hence should be viewed with caution. However, soils having free swell values below $50 \%$ are not 
normally expected to present any serious problems under light loads (Garg 2011). Therefore, the studied clays vary evidently between low to high swelling, and thus agree with the PI. The FS values suggested that the shale samples will show considerable volume change when wetted under light loads as seen figure 2 (Agbede and Smart 2007; Garg 2011). Thus, conventional shallow

Table 4. Slake durability classification (Bell 2007).

\begin{tabular}{lc}
\hline Durability & $\begin{array}{c}\text { Slake durability index } \\
\text { after } 10-\text { min cycle }\end{array}$ \\
\hline Very low & Under $25 \%$ \\
Low & $25-50 \%$ \\
Medium & $50-75 \%$ \\
High & $75-90 \%$ \\
Very high & $90-95 \%$ \\
Extremely high & Over $95 \%$
\end{tabular}

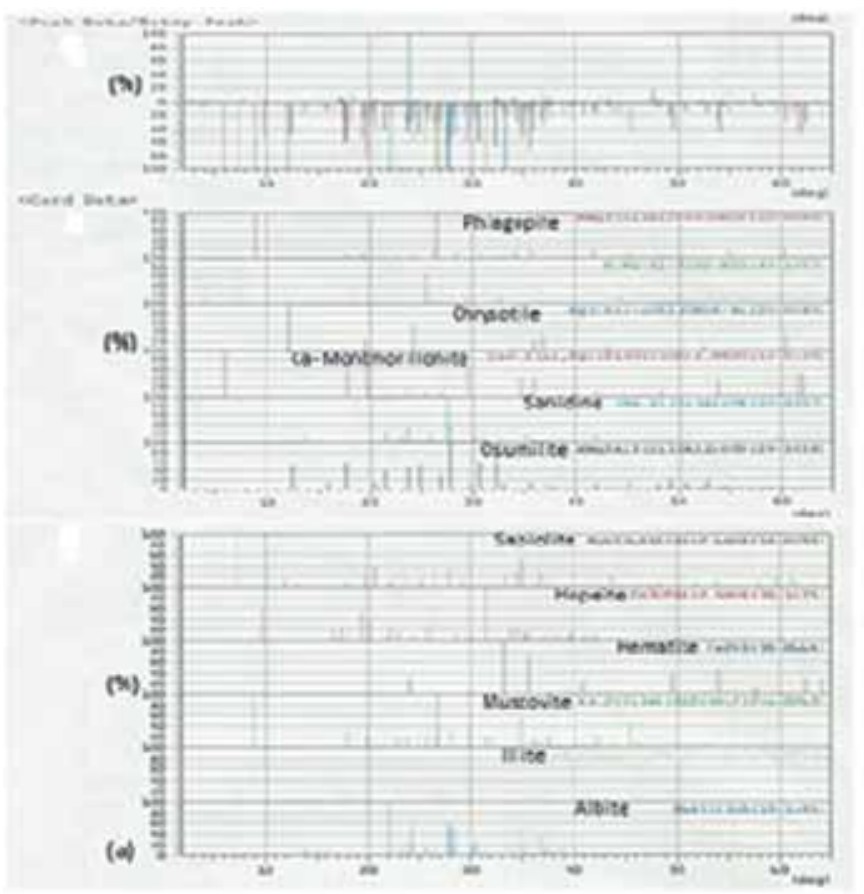

foundations will not be adequate on the shale (Garg 2011).

\subsection{Compaction capability}

Compaction test seeks to simulate the right combination of moisture (optimum moisture content, OMC) and load (compactive effort) on a soil that would result in increased density, and

Table 5. Proposed expansive soil rating (Tadanier and Nguyen 1984).

\begin{tabular}{llll}
\hline LL $(\%)$ & PI $(\%)$ & LS $(\%)$ & $\begin{array}{c}\text { Expansive } \\
\text { rating }\end{array}$ \\
\hline$<35$ & $<18$ & $<8$ & Low \\
$35-45$ & $18-25$ & $8-13$ & Medium \\
$45-60$ & $25-35$ & $13-18$ & High \\
$>60$ & $>35$ & $>18$ & Very high \\
\hline
\end{tabular}
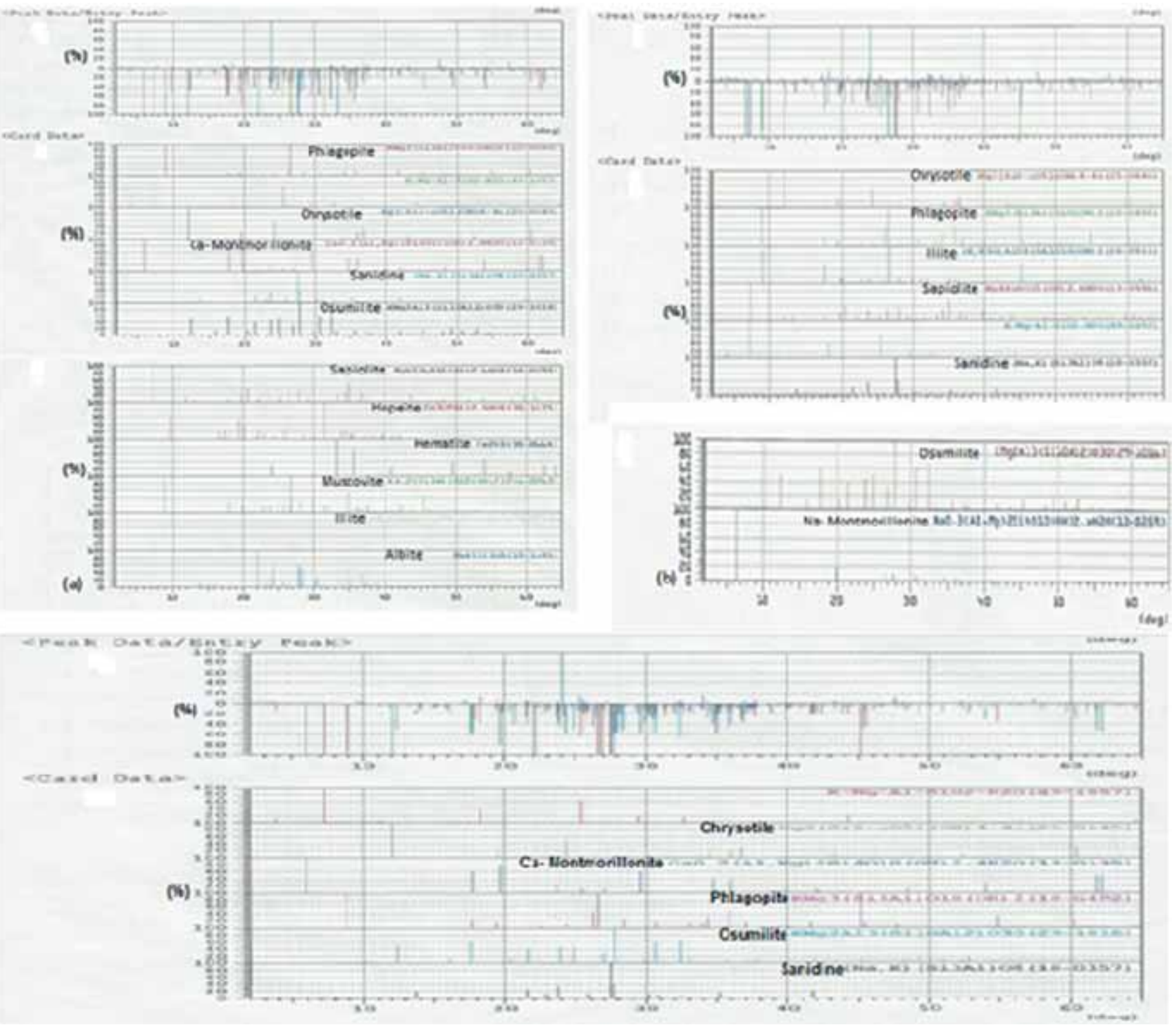

Figure 8. XRD scans' result. 

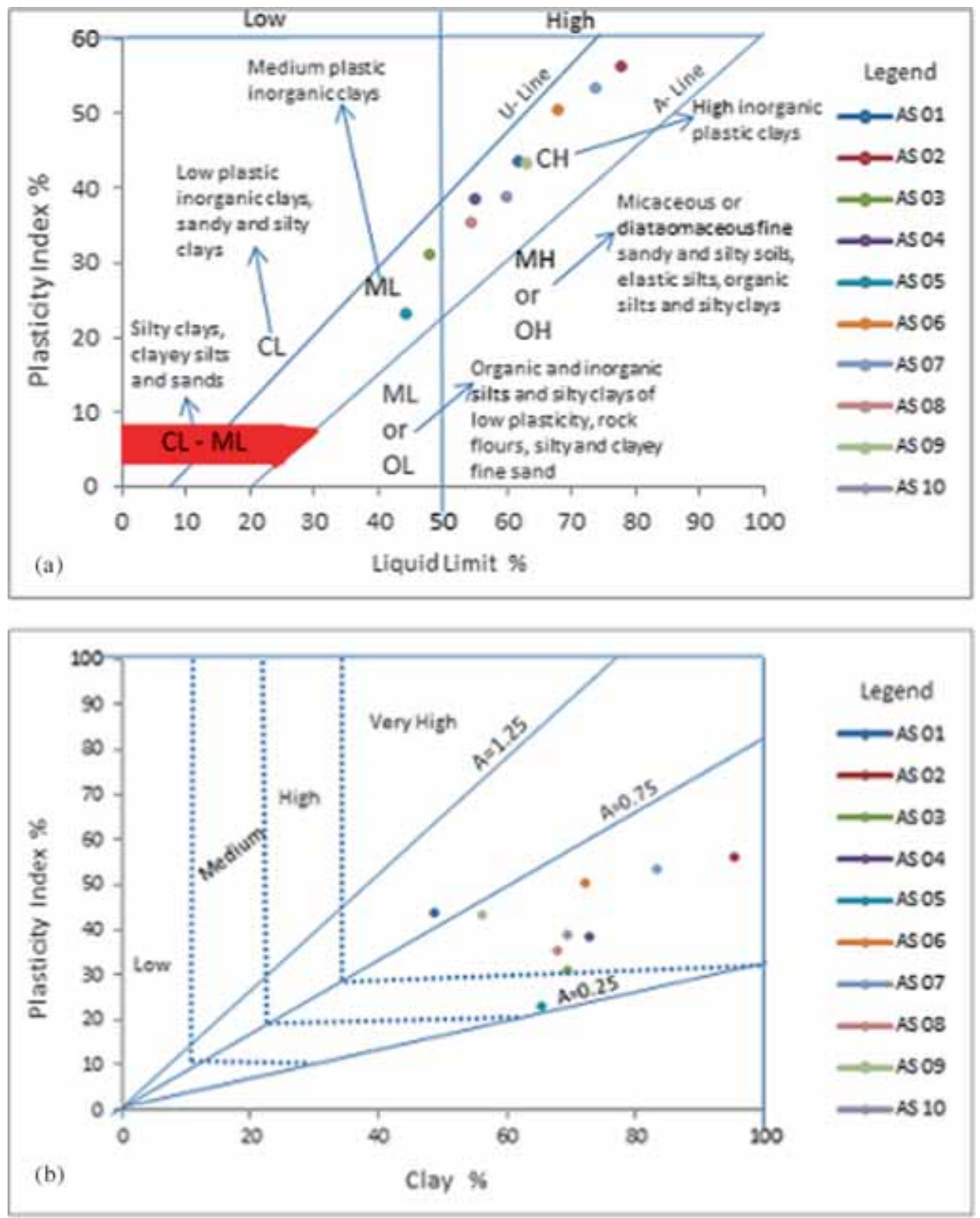

Figure 9. (a) Soil plasticity chart and (b) samples activity chart (after Lew 2010).

Table 6. Liquid limit and compressibility grading (Ezeribe 1994; Nwachukwu 1994).

\begin{tabular}{ll}
\hline Liquid limit & \multicolumn{1}{c}{ Compressibility } \\
\hline$<35 \%$ & Low compressibility \\
$35 \%-50 \%$ & Medium compressibility \\
$>50 \%$ & High compressibility \\
\hline
\end{tabular}

thus improve its appropriateness in construction projects. Results indicated that the smectite dominated samples (AS 04 and 08) achieved a maximum dry density (MDD) value of 1.92 and $1.94 \mathrm{~kg} / \mathrm{m}^{3}$ at OMC of $11.5 \%$ and $12.3 \%$ respectively (figure 10 ).

The OMC determined for non-smectite dominated samples (AS 03 and 05 ) are $8.4 \%$ and $6.9 \%$ and their corresponding MDD are 1.88 and $1.87 \mathrm{~kg} / \mathrm{m}^{3}$, respectively. Other non-smectite dominated samples (AS 09 and 10) that have OMC within the range of the smectite-dominated shale (9.0-10.0\%) achieved a higher MDD (1.91 and $\left.1.95 \mathrm{~kg} / \mathrm{m}^{3}\right)$. From the chart observations (figure 10), the smectitedominated samples only showed higher compaction (MDD) than the non-smectite samples at larger moisture intake as indicated by higher OMC. However, all the curves have a narrow bell-shaped form which is an indication of high plasticity clays (Arora 2008; Garg 2011). The higher MDD (>1.85 $\mathrm{kg} / \mathrm{m}^{3}$ ) which are close to the MDD of low plastic silt might be attributed to the high sand content of 20-49\%. Sample AS 02 with the lowest MDD (1.79 $\mathrm{kg} / \mathrm{m}^{3}$ ) might be as a result of low sand content of $3 \%$. 
As the grading curves depict (figure 5), samples 02 and 07 are finer than AS 03 and 05 with higher clay contents, and accordingly showed higher values of plasticity and volumetric shrinkage (LL, PI, LS and FS). Although the clay content of sample AS 03, 05 and 08 are higher than AS 01, the latter is characterized by higher value of PI and LL. It has also exhibited higher OMC. This implies that the swell-shrink ability of expansive soils influences their compaction characteristics.

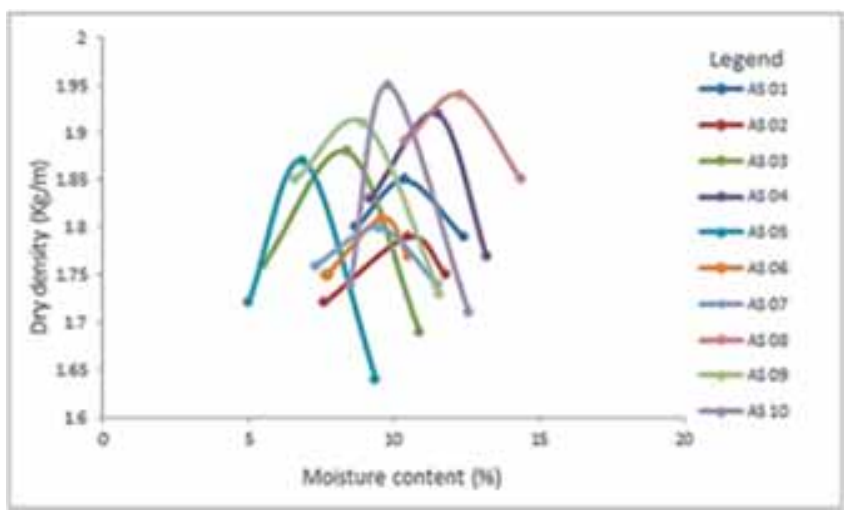

Figure 10. Soil samples compaction curves.

Table 7. Soil compaction grading (Emesiobi 2000).

\begin{tabular}{lc}
$\begin{array}{l}\text { Maximum dry density } \\
(\mathrm{MDD})\left(\mathrm{g} / \mathrm{m}^{\mathbf{3}}\right)\end{array}$ & $\begin{array}{c}\text { General value as a sub- } \\
\text { grade foundation material }\end{array}$ \\
\hline Over 2121 & Excellent \\
$1958-2121$ & Good \\
$1795-1958$ & Fair \\
$1632-1795$ & Poor \\
$1142-1632$ & Very poor \\
\hline
\end{tabular}

In addition to compactive effort, nature of the compacted samples and moisture condition of the shale must have impacted on the fair MDD values. The use of standard Proctor method, high sand content and presence of little (comparatively $<20 \%$ ) amount of water due to moisture retaining minerals in the samples might have contributed to the average MDD values (Bell 2007). However, according to compaction grading shown in table 7 , the MDD for the tested samples are rated as nonsatisfactory for base material and are graded as poor to fair for sub-grade foundation material.

The relative poor to fair MDD could also be attributed to unconsolidation due to low cementing materials, giving rise to high air voids. Smectite does not survive in sediments that have undergone burial at great depth of about $4 \mathrm{~km}$ (Weaver 1959) or that have experienced high consolidation due to metamorphism (Borchardt 1989). Also, it is likely that the foundations in the area are sitting on highly weathered soil materials where smectites are predominant due to the weathering of feldspars into clay minerals (figure 11). The reason for high OMC might be associated with high content of clay minerals.

Clay samples from the study area have Natural Moisture Content (NMC) and Bulk Density (BD) between $7.2-14.6 \%$ and $1.5-2.18 \mathrm{mg} / \mathrm{m}$ respectively (table 2 ). The $\mathrm{BD}$ values agree with the findings reported by Ross Seedman (1986) and Hong et al. (2012); that osmotic swelling of clay shale occurs in samples with bulk density less than $2.45 \mathrm{mg} / \mathrm{m}^{3}$. The very high activity of smectite minerals enhances their ability to absorb water in the form of adsorbed water on its surfaces and

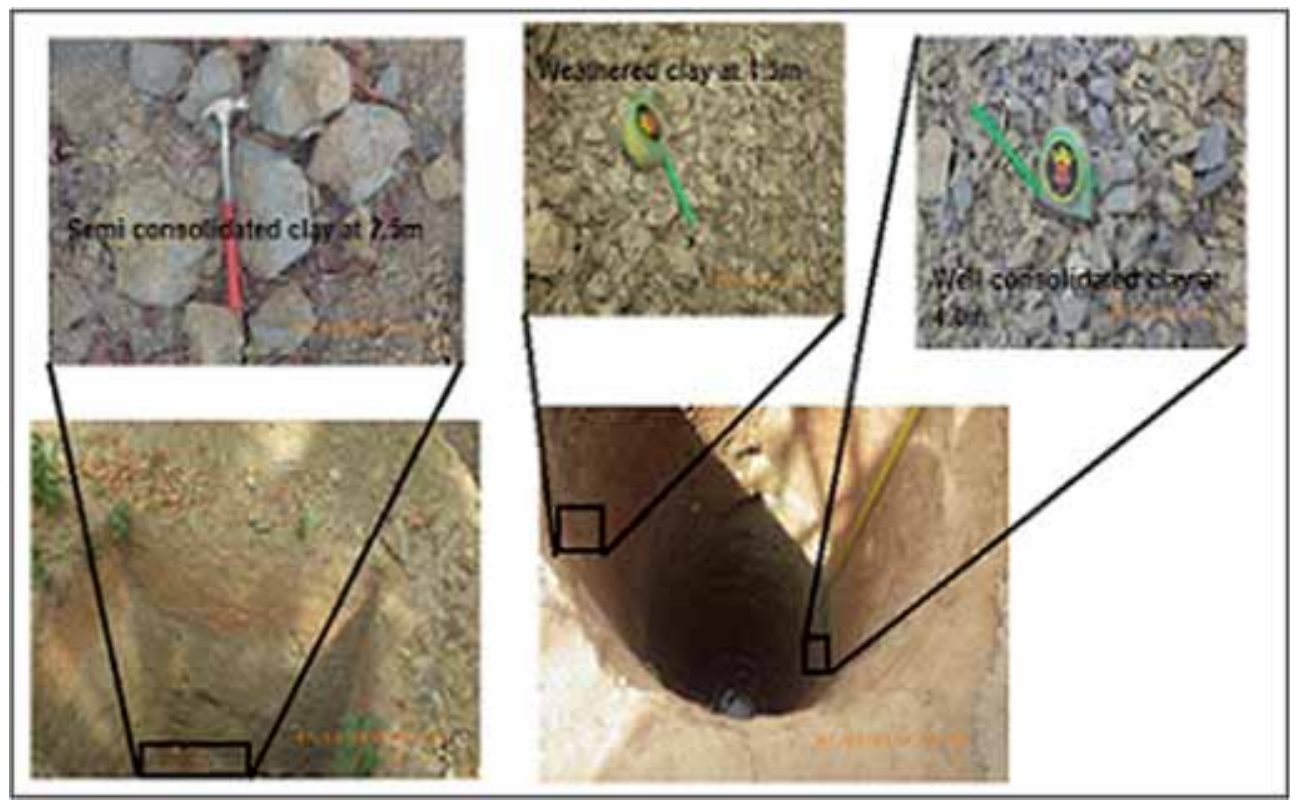

Figure 11. Degrees of consolidation and weathering. 


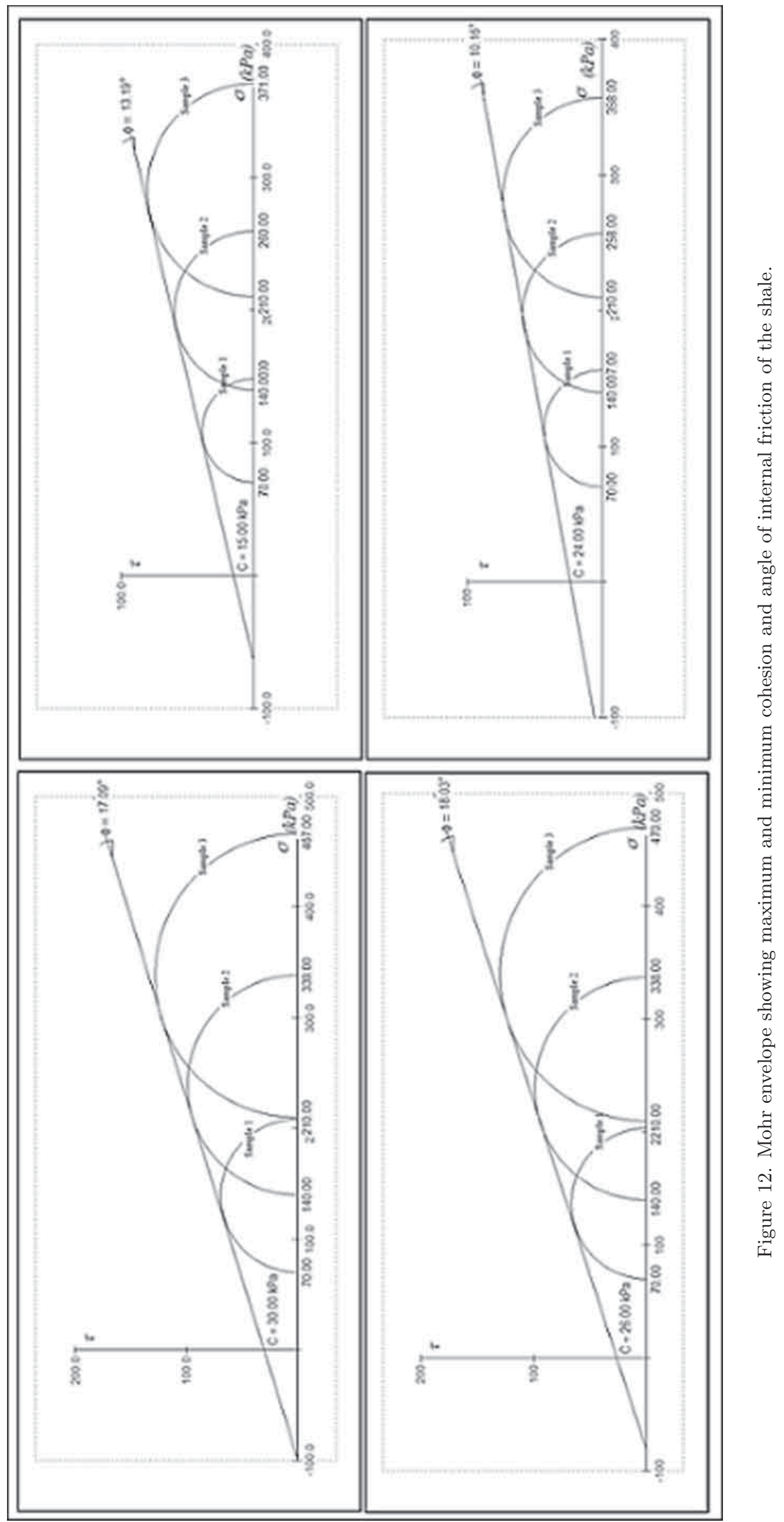


increases the natural moisture content. These high values of $\mathrm{NMC}$ and $\mathrm{BD}$ convey the reason for the relatively high unit weighs $(\Upsilon)$ of the shale which registered values between 19.2 and $20.7 \mathrm{kN} / \mathrm{m}^{3}$ (table 2).

\subsection{Soil shear strength}

A summary of the shear strength parameters (cohesion and angle of internal friction) of the tested samples are presented in table 2. The Mohr Envelopes of the highest and lowest of cohesion and internal friction angle are shown in figure 12 . Cohesion of the tested shale ranges from 15 to $30 \mathrm{kPa}$ while the internal friction angle ranges between $10^{\circ}$ and $18^{\circ}$. These values of cohesion and internal friction angle are suggestive of an average shear strength and thus, pose no bearing capacity challenge (Arora 2008; Aghamelu et al. 2011a, b).

Shale that are predominated only by clays and are as well non-cemented, most often record very low values of friction angle close to $10^{\circ}$ (Punmia et al. 2005). Therefore, the studied shale might be considered as non-durable for foundations and construction materials. However, average values of cohesion $(26 \mathrm{kPa})$ recorded mean an average cohesive material, similar to normal consolidated clay and other materials with high clay content, and could be suggesting that the shale have considerable strength, likely to withstand shear stresses (Aghamelu et al. 2011a).

Soil structures, swelling and cementation are the main factors affecting the shear strength of clays (Feda 1995; Cheng et al. 2004). But, water content also has some secondary effect (Dimitrova and
Yanfu 2011). Therefore, poor cementing material and high swelling potential might have a strong affinity for each other and may be responsible for the average shear strength that eventually could deteriorate at the foundation site, as suggested by the $G_{s}$ and $I_{d}$ values, especially in the presence of water. Moisture influx would deteriorate the clays, particularly its constituent minerals and cements, resulting in strength reduction and perhaps, bearing capacity during the engineering life of such projects (Aghamelu et al. 2011b).

\subsection{Comparison of Awgu Shale properties with other expansive shale and the Nigerian specification for construction}

The Awgu Shale recorded high swelling potential when compared with other $\mathrm{CH}$ classified expansive shale in southern Nigeria such as the Abakiliki and Igumale Shales (table 8). Abakiliki Shale is a member of the Azu River Group while the Igumale Shale is a lateral equivalent of the Eze-Aku Shale, deposited during the Albian and Turonian age respectively. Abakiliki and Igumade recorded LL and PI of 60 and $40 \%$ and 72 and $45 \%$ respectively, which are lower than $45-78 \%$ and $23-$ $56 \%$ recorded by the Awgu Shale. The free swell of Awgu Shale were very high (45-145\%) when compared to the average of $49 \%$ and $50 \%$ registered by Abakiliki and Igumale Shales, respectively. However, Agwu showed slightly lower shrinkage values (13-21\%) in comparison with both Abakiliki Shale and Igumale Shale (21\%).

The compacted Awgu Shale achieved a mean MDD value $\left(1.87 \mathrm{~kg} / \mathrm{m}^{3}\right)$ significantly higher than

Table 8. Comparison of properties of the Awgu Shale with those of other expansive soils in southern Nigeria.

\begin{tabular}{lcll}
\hline Soil properties & Igumale Shale & Abakiliki Shale & Awgu Shale \\
\hline Fines & 90 & 91 & $51-97$ \\
LL $(\%)$ & 72 & 60 & $45-78$ \\
PL (\%) & 27 & 20 & $17-22$ \\
PI (\%) & 45 & 40 & $23-56$ \\
LS (\%) & 21 & 21 & $13-21$ \\
FS (\%) & 50 & 49 & $45-145$ \\
USC classification & CH & CH & CH \\
AASHTO classification & A-7-6 & A-7-6 & A-7-6 \\
MDD (kg/m $\left.{ }^{3}\right)$ & 1.50 & 1.86 & $1.79-1.95$ \\
OMC $(\%)$ & 22 & 12 & $7-12$ \\
NMC $(\%)$ & 25 & 25 & $7-15$ \\
Gs & 2.55 & 2.50 & $2.50-2.58$ \\
C (kPa) & Untested & 51 & $15-30$ \\
$\varnothing^{\circ}$ & Untested & 28 & $10-18$ \\
Colour & Grey & Bluish/brownish & Yellowish brown/ \\
& & & bluish grey
\end{tabular}

*Data from Manasseh and Olufemi (2008) and Aghamelu and Okogbue (2011). 
Table 9. Comparison of Awgu Shale properties with the Nigerian specification for construction (adpted from Aghamelu and Okogbue 2011).

\begin{tabular}{|c|c|c|c|}
\hline Properties of materials & $\begin{array}{c}\text { Nigerian } \\
\text { specification }\end{array}$ & Awgu Shale & Remarks \\
\hline \multicolumn{4}{|l|}{ General filling and embankment } \\
\hline $\operatorname{MDD}\left(\mathrm{kg} / \mathrm{m}^{3}\right)$ & $>0.047$ & $1.79-1.95$ & \\
\hline Optimum moisture content, OMC (\%) & $<18$ & $6.9-12.3$ & \\
\hline Liquid limit, LL (\%) & $<40$ & $45-78.0$ & Poor to fairly satisfactory \\
\hline Plastic index, PI (\%) & $<20$ & $23-56$ & \\
\hline Passing no. $200(\%)$ & $\leq 35$ & $51-97$ & \\
\hline Soaked CBR at British standard & $>5$ & Not tested & \\
\hline \multicolumn{4}{|l|}{ Sub-base course } \\
\hline Liquid limit, LL (\%) & $<35$ & $45-78.0$ & \\
\hline Plastic index, PI (\%) & $<16$ & $23-56$ & Likely to be unsatisfactory \\
\hline $\begin{array}{l}\text { CBR at west African standard } \\
(\%) \text { and optimum moisture con- } \\
\text { tent, OMC }(\%)\end{array}$ & $\geq 25$ & Not tested & \\
\hline \multicolumn{4}{|l|}{ Base course } \\
\hline Liquid limit, LL (\%) & $\leq 30$ & $45-78.0$ & \\
\hline Plasticity index, PI (\%) & $\leq 13$ & $23-56$ & Likely to be unsatisfactory \\
\hline Unsoaked CBR at modified AAHTO and OMC & $\geq 80$ & Not tested & \\
\hline
\end{tabular}

the Igumale Shale $\left(1.51 \mathrm{~kg} / \mathrm{m}^{3}\right)$ but approximately the same with the Abakiliki Shale $\left(1.86 \mathrm{~kg} / \mathrm{m}^{3}\right)$. The reason for higher MDD could be accredited to the presence higher clay content and calcite with specific gravities of 2.44-2.92 and 2.6-2.7 respectively. However, all three shales (Awgu, Abakiliki and Igumale) have close mean specific gravity values $(2.55,2.50$ and 2.55 , respectively).

Awgu Shale recorded significantly lower values of cohesion $(26 \mathrm{kPa})$ and friction angle $\left(14^{\circ}\right)$ when compared with the Asu-River (Abakiliki) Shale which has mean cohesion and friction angle of 51 $\mathrm{kPa}$ and $28^{\circ}$, respectively. The higher cohesion of the Abakiliki Shale is ascribed to the calcareous nature of the shale (Blyth and De Feritas 1984), while the low friction angle of the Awgu Shale is attributed to higher expansive capabilities. The Abakiliki Shale having marginally better geotechnical properties (table 8) could be attributed to the baking effect that affected the Abakiliki flank of the Benue Trough during the Santonian tectonic events. The general finding agrees with the report of Ekeocha (2014), which opined that Awgu Shale might have the poorest geotechnical capability in comparison with other expansive clays of the Anambra Basin in southern Benue Trough.

A comparison of the geotechnical properties of the Awgu Shale with the Nigerian specification standard for construction revealed that the shale did not fulfill all the specifications for construction material, with respect to fills and embankments (table 9). Despite having satisfactory values of MDD, OMC, c and $\varnothing$, the shale recorded high LL, PI and NMC suggesting unseemliness as an engineering material. However, there is a possibility of stabilization of the shale owing to the fact that it possesses some good qualities such as compaction and strength abilities.

\section{Conclusion}

The conclusions of the evaluation indicated that the Agwu Shale is predominantly clays of medium to highly expansive capability and high waterholding capacity due to the presence of smectite and illite. The clay compaction is poor to fair for construction purposes due to unconsolidation or weathering of the soil. The soil strength and bearing capacity could be, on an average, good for foundation soil. But, moisture influx could reduce the strength of the soil due to deterioration of the constituent minerals. Therefore, we submit to the fact that the cracks on the walls of engineering structures underlain by the Awgu Shale are generally caused by structural movements initiated by expansive soil behaviours.

\section{Recommendation}

An understanding of the poor geotechnical quality of expansive shale as a construction material or aggregate will help building engineers in the design and maintenance of engineering structures. Thus, we recommend that:

- Appropriate foundation design should be applied. As such, foundations must be heavy, 
rigid and must be of great strength in order to withstand heave stresses on engineering structure or deeper so as to carry the load to the stable soil below the active zone.

- Foundation material modification is necessary. This requires the removal and replacement of shale with free draining granular sand or shale treatment and stabilization by grouting using high calcium content materials (Mir and Sridharan 2013).

- Good drainage control must be seriously encouraged by constructing foundations during the dry season when the shale has shrunk to its lowest level and arrangement must be made to drain away water from the shale through artificial or surface drainage systems and dredging of river channels with the intention to avoid flooding, which increases moisture content in the shale.

\section{Acknowledgement}

The authors' appreciation goes to the staff of National Steel Raw Materials Exploration Agency, Kaduna, Nigeria, for their contributions in making this research a success.

\section{References}

Adesina R, Tijani M and Wagner J F 2012 Geotechnical and geochemical assessment of shales in Anambra Basin, southeastern Nigeria as compacted clay liner in landfills; In: Conf. Proc. Clay in Natural and Engineering Barriers for Radioactive Waste Confinement, Montpellier, France, INIS 44(24).

Adesunloye M O 1987 Investigating the Problem Soils of Nigeria; 9th Reg. Conf. for Africa on S.M.F.E. Lagos, pp. 103-112.

Adeyemi G O 2002 Geotechnical properties of lateritic soil developed over quartz schist in Ishara area southwestern Nigeria; J. Mining Geol. 38(1) 65-69.

Agbede I O and Smart P 2007 Geotechnical properties of Makurdi Shale; Nigerian J. Technol. 26(2) 63-73.

Aghamelu O P and Okogbue C O 2011 Geotechnical assessment of road failures in the Abakiliki Area, southeastern Nigeria; Int. J. Civil Environ. Eng. 11(2) 12-21.

Aghamelu O P, Nnabo P N and Ezeh H N 2011b Geotechnical and environmental problems related to shales in the Abakaliki area, southeastern Nigeria; African J. Environ. Sci. Technol. 5(2) 80-88.

Aghamelu O P, Odoh B I and Egboka B C E 2011a A geotechnical investigation on the structural failures of building projects in parts of Awka, southeastern Nigeria; Indian J. Sci. Technol. 4(9) 1119-1124.

Arora K R 2008 Soil Mechanics and Foundation Engineering; 7th edn, Standard Publishers Distributors, Nai-Sarak, Delhi, pp. 875-890.

Arua I 1988 Episodic sedimentation: An example from the Nkporo Shale (Campano-Maastrichtian) Nigeria; J. African Earth Sci. 7 759-762.

Asere A A, Egwurube J A, Salawu O B E and Tokan A 2002 The effect of major road wash-away on highway construction: A case study from northern Nigeria; NJTE 15(1) 26-40.
Bell F G 2007 Engineering geology; 2nd edn, London, Elsevier, pp. 207-248.

Benkhelil J 1986 Structure and evolution geodynamics of the Benue Trough Intracontinental Basin; University Nice, 226p.

Benkhlil J 1989 The origin and evolution of the Cretaceous Benue Trough (Nigeria); J. African Earth Sci. Middle East 8(2) 251-282.

Berry P L and Reid D 1987 An Introduction to Soil Mechanics; McGraw-Hill Book Co., London, 317p.

Blyth F G H and De Feritas M H 1984 A Geology for Engineers, 7th edn, Arnold Intern Students's edn, Arnold Publishing, London, 325p.

Borchardt G 1989 Smectites; In: Minerals in soil environments, 2nd edn, (eds) Dixon J B and Weed S B, Madison, WI, Amsterdam Soil Sci. Soc. 1 675-727.

British Standard Institution (BSI) 13771990 Methods of Testing Soils for Civil Engineering Purposes; British Standard Institute, London.

Cheng X, Jaussen H, Barends F B J and den Haan E J 2004 A combination of ESEM, EDX and XRD studies on the fabric of Dutch Organic Clay from Ostvaardersplassen (Netherlands) and its geotechnical implications; Appl. Clay Sci. 25 179-185.

Cratchley G R and Jones G P 1965 An interpretation of the geology and gravity anomalies of the Benue Valley, Nigeria; In: Overseas Geological Survey, Geophysical Paper (1).

De-Swardt A M and Casey O P 1963 The coal resources of Nigeria; Bull. Geol. Surv. Nigeria 28.

Dimitrova R S and Yanfu E K 2011 Undrained strength of deposited mine tailings beds: Effect of water content, effective stress and time of consolidation; Geotech. Geol. Eng. 29(5) 935-951.

Ekeocha N E 2014 Geotechnical implications of using shale as subgrade materials; Asian Trans. Sci. Technol. 4(2), (ATBAS ISSN: 2221-4283).

Emesiobi F C 2000 Testing and Quality Control of Material in Civil and Highway Engineering; Blue Print Publishers, Port Harcourt.

Ezeribe I E 1994 The characterization of some Nigeria shales relative to their engineering uses; MSc Thesis, University of Nigeria, Nsukka.

Feda J 1995 Behaviour of cemented clay; Canadian Geotech. J. 32 899-904.

Garg S K 2011 Soil Mechanics and Foundation Engineering; 8th edn, Khanna Publishers, Daryaganj, New Delhi, pp. $763-776$.

Gupte S S, Singh R, Vishal V and Singh T N 2013 Detailed investigation of stability of in-pit dump slope and its capacity optimization; Int. J. Earth Sci. Eng. 6(2) $146-159$.

Holtz R D and Kovacs W D 1981 Introduction to Geotechnical Engineerig; New Jersey, Prentice-Hall, 733p.

Hong J C, Jong K M and Il S J 2012 A study of decreasing behavior of strength and elastic parameters due to water infiltration in rock cores; J. Korean Geotech. Soc. 28(1) 69-83.

Igwesi D I and Umego M N 2013 Interpretation of aeromagnetic anomalies over some parts of lower Benue Trough using spectral analysis technique; Int. J. Sci. Technol. Res. 2(8) 153-165.

Johnson L D and Snethen D R 1978 Prediction of potential heave of swelling soil; Geotech. Test. J. 1(3) 117-124.

Kettler T A, Doran John W and Gilbert T L 2001 Simplified method for soil particle-size determination to accompany soil-quality analyses; Soil Sci. Soc. Am. J. 65 849-852.

Kogbe C A 1989 The Cretaceous and Paleogene sediments of southern Nigeria; In: Geology of Nigeria (ed.) Kogbe C A, Elizabethan Publ. Co, Lagos, pp. 325-334. 
Krynine D P and Judd W R 1957 Principles of Engineering Geology and Geotechnics; McGraw-Hill, New York, 730p.

Lambe T W 1951 Soil Testing for Engineers; Wiley, New York, 165p.

Le T, Fatahi B and Khabbaz H 2012 Viscous behaviour of soft clay and inducing factors; Geotech. Geol. Eng. 30(5) 1069-1083.

Lew B 2010 Structure damage due to expansive soils: A case study; J. Geotech. Eng. EJGE 15 1317-1324.

Liu C W and Lu S L 2000 Research on mechanism of mudstone degradation and softening in water; Rock and Soil Mechanics 21(1) 28-31.

Madedor A O 1983 Engineering properties of black cotton soil in Nigeria and related pavement design; Nigeria Building and Road Research Inst. Research Paper 1 1-22.

Manasseh J and Olufemi A I 2008 Effect of of lime on some geotechnical properties Igumale shale; Electronic J. Geotech. Eng. 3 1-12.

Mir B A and Sridharan A 2013 Physical and compaction behaviour of clay soil-fly ash mixtures; Geotech. Geol. Eng. 31(4) 1059-1072.

Mitchell J K 1993 Fundamentals of Soil Behavior, 2nd edn, University of California, Berkeley, John Wiley \& Sons, Inc., 437p.

Monanu S and Inyang F 1975 Climatic regimes; In: Nigeria in maps (ed.) Ofomata G E K, Benin, Ethiope Publ. House, pp. 27-29.

Murat C 1972 Stratigraphy and paleogeography of the cretaceous and lower tertiary in south-eastern Nigeria; In: African geology (eds) Whiteman A J and Dessauvagie T F J, Ibadan University Press, pp. 251-266.

Nwachukwu M 2012 Geotechnical assessment of road failure along Adoru-Nsukka-Uzouwani Highway, Enugu State, Nigeria; MSc Thesis, University of Nigeria, Nsukka.

Nelson J D and Miller D J 1992 Expansive soils, problems and practice in foundation and pavement engineering; John Wiley and Sons, New York, 259p.

Obaje N G 1994 Coal of cretaceous petrography, microfossils and paleoenvironments coal measures in the middle Benue Trough of Nigeria; Tuebinger Mikropalaeontologische Mitteilungen 11 1-165.

Obi G C, Okogbue C O and Nwajide C S 2001 Evolution of the Enugu Cuesta: A tectonically driven erosional process; Global J. Pure Appl. Sci. 7 321-330.

Obiora S C and Umeji A C 2004 Petrographic evidence for regional burial metamorphism of the sedimentary rocks in the lower Benue Rift; J. African Earth Sci. 38(3) 269-277.

Okiwelu A A, Okwueze E E, Akpan P O and Ude I A 2015 Basin framework and basement structuring of lower Benue Trough, West Africa based on regional magnetic field data: Tectonic and hydrocarbon implications; Earth Sci. Res. 4(1).

Olayanju G M 2011 Engineering geophysical investigation of a flood zone: A case study of Alaba Layout, Akure, southwestern Nigeria; J. Geol. Mining Res. 3(8) 193-200.

Oyedim G C, Alagoa K D, Adedokun I O, Aderogb A A and Ovuru C C 2009 Mapping high-angle basement faults in the middle Benue Trough Nigeria from gravity inversion surface; Earth Sci. Res. J. 13(2) 140-147.
Petters S W 1978 Stratigraphic evolution of the Benue Trough and its implication for the Upper Cretaceous paleogeography of West Africa; J. Geol. 86 311-322.

Pradhan S P, Vishal V, Singh T N and Singh V K 2014 Optimisation of dump slope geometry vis-à-vis flyash utilisation using numerical simulation; Am. J. Mining Metallur. 2(1) 1-7.

Punmia B C, Ashok K J and Aun K J 2005 Soil Mechanics and Foundations; Lexmi Publications Ltd., pp. 62-66.

Reidenouer D R 1970 Shale suitability. Phase II: Pennsylvania Department of Transportation, Bureau of Materials, Testing and Research, Interim Rep. 1198.

Reyment R A 1965 Aspects of the geology of Nigeria; Ibadan University Press, Nigeria, 145p.

Reyment R A 1969 Ammonite biostratigraphy, continental drift and oscillatory transgressions; Nature $\mathbf{2 2 4}$ $137-140$.

Sarkar K, Vishal V and Singh T N 2012 An empirical correlation of index geo-mechanical parameters with the compressional wave velocity; Geotech. Geol. Eng. 30 469-479.

Seedman R 1986 The behavior of clay shales in water; Canadian Geotech. J. 23(1) 18-22.

Sharma P K, Khandelwal M and Singh T N 2007 Variation on physico-mechanical properties of Kota Stone under different waterly environment; Build. Environ. 4(12) 4117-4123.

Shell B P 1957 Geological map, Sheet Enugu 64:1:250000, Nigeria.

Sheriff R E 1991 Encyclopedic Dictionary of Exploration Geophysics; Society of Exploratory Geophysicists, Tulsa.

Singh T N and Verma A K 2005 Prediction of creep characteristics of rock under varying environment; Environ. Geol. 48 559-568.

Singh T N, Goswami S K, Sharma P K and Sharma Y C 2006 Chemical analysis of Gaula river water and adjoining hill side tension crack water near Amiya Village, Nainital; Indian J. Environ. Protect. 26(10) 865-871.

Sowers G B and Sower G E 1970 Introductory Soil Mechanics and Foundations; Macmillan Book Publishing Company, London, 337p.

Tadanier R and Nguyen V V 1984 Index properties of expansive soils in New South Wales; 5th Internal Conference on Expansive Soils, Adelaide, South Australia.

U S Geological Survey 2001 Open-files Report - 01-041.

Van der Merwe D H 1964 The prediction of heave from the plasticity index and the percentage clay fraction; Civil Eng. South Africa 6(66) 103-107.

Vishal V, Jain N and Singh T N 2015a Three dimensional modelling of propagation of hydraulic fractures in shale at different injection pressures; Sustain. Environ. Res. 25(4) $217-225$.

Vishal V, Pradhan S P and Singh T N 2015b An investigation on stability of mine slopes using two dimensional numerical modelling; J. Rock Mechanics \& Tunnelling Technology (JRMTT) 21(1) 49-56.

Weaver C E 1959 The Clay petrology in sediments; Clay Mineral. 6 154-187.

MS received 15 February 2016; revised 17 May 2016; accepted 23 May 2016

Corresponding editor: R K SRIVASTAVA 